\title{
Felsefi Soruşturmalar'da Oyun Kavramının Kuruluşu Üzerine Wittgenstein
}

\author{
Wittgenstein: On the Constitution of the Game Concept in Philosophical \\ Investigations
}

\section{Sercan ÇALCI*}

Özet: Bu yazıda, Ludwig Wittgenstein'ın dil oyunları kuramının en önemli bileşenlerinden birisi olan oyun kavramının Felsefi Soruşturmalar'daki evrimi inceleniyor. Wittgenstein'ın Tractatus'ta ortaya koyduğu dil felsefesinin sınırlı evreninden dil oyunlarının çoklu dünyasına geçişinde hem bir metafor hem de bir kavram olarak rol oynuyor oyun sözcüğü. Anlamın kullanım kavramıyla birlikte düşünüldüğü bu yeni bağlamda artık gündemde olan bir meta-dil arayışı değil, dil-oyunlarının gündelik dil içerisinde yarattı̆̆ı anlam akışlarıdır. Bu bağlam, dili yalnızca temsili bir sistem olarak görmek yerine onu yeni ifade olanaklarının alet çantası olarak görmeyi mümkün kılıyor.

Anahtar Sözcükler: Wittgenstein, oyun, dil-oyunları, emir, arzu, anlam, kullanım

Abstract: In this text, the evolution of the concept of game in Philosophical Investigations is studied as one of the most significant components of the language-game theory. Word game plays a part both as a metaphor and a concept in Wittgenstein's transition from the restricted universe of the philosophy of language presented in Tractatus to the multiple world of language-games. In this new context in which sense is discussed with the concept of using, a search for a meta-language is no longer at issue but the sense-flux that language-games produce in daily language. This context makes possible an approach in which language can be taken as a tool box for the possibilities of new expressions instead of a representative system.

Keywords: Wittgenstein, game, language-game, order, desire, sense, using

"Yalan söylemek öğrenilmesi gereken bir dil-oyunudur, diğerlerinin hepsi gibi".

Ludwig Wittgenstein

"Doğru cevabı satranç olan bir bilmecede geçmeyen tek sözcük hangisidir?" diye sorar Stephen Albert ve Yu Tsun şöyle cevap verir: "satranç sözcüğ̈̈̈" (Borges, 2007, 86). Borges'in Yollarl Çatallanan Bahçe'sinde Çinli bilge Ts'ui Pen'in yapıtı da zaman sözcügünü bir kez bile anmayan ama aslında zaman üzerine bir bilmeceye dönüşen, bir yerlerde bulunduğu varsayılan labirentin ta kendisidir: yapıt, zaman, labirent...

Wittgenstein'ın Felsefi Soruşturmalar'1 için Borges'in sorusunu şöyle soruyoruz: "yanıtı dil-oyunları olan bir sorunun her soruluşunda geçen sözcük hangisidir?" Yu Tsun şöyle cevap verebilir: Tabii ki oyun sözcüğü.

Çinli bilge Ts'ui Pen'in romanında mutlak bir zaman kavrayışının ötesinde tüm olasılıkları içine alan, çatallanan bir zaman ya da sonsuz zaman dizileri diyebileceğimiz bir zaman anlay1şıyla karşılaşır Stephen Albert ve şöyle söyler: "Zaman sayısız geleceğe doğru çatallanıyor.

\footnotetext{
*Arş. Gör., Akdeniz Üniversitesi, Edebiyat Fakültesi, Felsefe Bölümü, sercan.calci@yahoo.com
} 
Bunlardan birinde ben sizin düşmanınızım" (Borges, 2007, 89). Ts'ui Pen aslında bir bilmece, bir labirent inşa eder: sözünü ettiği labirent tam da metinde örülü olan sonsuz zaman ve olasılık dizilerinin labirentidir. Felsefi Soruşturmalar belki de kendisi oyuna, dil oyununa dönüşen, oyun üzerine bir metin olarak okunmalıdır; içinde labirentin bir tarifi bulunan bir labirent-oyun olarak:

\section{"203. Dil, yollardan oluşan bir labirenttir. Bir yönden geldiğinde yolunu bilmektesindir; aynı yere başka bir yönden geldiğindeyse yolunu kaybet- mişsindir artık" (Wittgenstein, 2007, 100).}

Bir metni sınırlarında okuma denemesi değişik perspektiflerden birçok soruyu gerektirecektir. Örneğin birçok yorumcunun söylemiş olduğu gibi oyun kavramı Felsefi Soruşturmalar içerisinde aslında bir tür "oyun analojisi"ne mi dönüşmüştür? Yani oyunlarla dil arasında bir tür benzerlik ilişkisi olarak mı kurulmuştur ilişki? Bir metafor mudur yoksa oyun sadece, bir tür model mi? Peki bir oyun icat edilebilir mi? Ve Wittgenstein'ın da sorduğu gibi buradaki “...ebilir" ne anlama gelmektedir? Bir oyun sadece kuralların bilinmesiyle oynanabilir mi? Örnek olarak satranç oynayabilmek için satranç taşlarının adlarını bilmek yeterli değildir, sözcüklerle bir oyun oynayabilmek için de sözcükleri artık sadece nesnelerin adları olarak düşünmek yeterli değildir. Peki, satranç kurallarını ve taşların adlarını biliyorsam satranç oynayabileceğimi iddia edebilir miyim? İddialarımız da bir tür oyunun, bir yaşama bağlamının parçaları değil midir? Peki ya kural ihlalleri, bunlar da bir kuralın öğrenilme süreçlerine dahil değil midir?

Wittgenstein'ın Felsefi Soruşturmalar'da betimlediği dünya, yaşamdaki deneyimlerin farklı ve paradoksal yapısını göstermektedir. Kurallar tarafından değil de kendi evrimleri tarafindan belirlenen tekillikler olarak oyunlar, bu paradoksal yapıyı taşıyan güçlü imgeler olarak düşünülebilir. Bu açıdan kuralların oyunları belirlediği geleneksel oyun kavramlarının terk edildiği bir metinle karşı karşıyayız. Kural ve oyun ilişkisi basitçe bir neden-sonuç ilişkisi olarak düşünüldüğünde artık dikotomik bir mantığın tüm oyun sürecini gölgelediği bir hiyerarşi kurulmaya başlar. Kural belirleyici olan oyun da belirlenen olur biter; sanki oyunlar olmaksızın kurallar tek başına varmış gibi. Wittgenstein bu tehlikenin, metafiziğin her yere sızan aşkın ve dikotomik yapısının, tümüyle farkındadır. Sıradan bir özne-nesne ilişkisinin oyunları kavramak için yeterli bir bakış açısı sağlamadığı ortadadır. İşte yapılması gereken tam bu anda oyunlara süreçler olarak bakmaktır, tamamlanmamış, bitmemiş, bir sona doğru ilerlemeyen süreçler olarak. Bunun en iyi ifadesini Felsefi Soruşturmalar'1n 83. fragmanında görürüz. Oyunlar, süreçlerdir ve kurallar da süreçler içerisinde konulur. Oyunu önceleyen hiçbir değişmez kural olamaz. Oyun, kuralın nesnesi değildir. Kurallar yalnızca işaretlerdir, hatta Wittgenstein kuralları yol levhalarına benzetir (Wittgenstein, 2007, 59). Şimdi, bir kuralın ardında ne aramalı? Yani kuralların koyulmasını belirleyen kurallar da var mıdır? Arkasında başka bir kural yoksa kural koymanın kendisi kuralsı bir şey mi olacaktır? Bu sonsuza kadar geri götürülebilir bir dizi olmaya mahkumdur. Kuralı belirleyen şey nasıl olur da kuralsız olabilir? Bu temel, eğer varsa, nerede aranmalı? İşte oyun kuramı bize dil-oyunlarının sürecine aşkın herhangi bir sabit kuralın olamayacağını göstermekle birlikte bu şekilde tasarlanan bir kuralın temelsiz olduğunu da düşündürür. Öyleyse yapılması gereken iki şey vardır. Birincisi kuralların da birer dil-oyunu olarak oluşturulduğunu betimleyecek bir oyun kavramı üretmektir. $\mathrm{Bu}$ yolla Wittgenstein düşüncesi, hem özel bir duyum olarak ağrı sözcüğüyle oynanan oyunların özel bir dil oluşturup oluşturamayacağını soruşturur hem de emir ve arzu sözcükleriyle oynanan dil-oyunlarının yapısını çözümlemeyi başarır. İkincisi ise, anlamı belirleyenin nesneyle sözcük arasındaki uyum ya da karşılık gelme üzerinden değil; sözcüklerin çoklu kullanımları yoluyla düşünüldüğü bir bağlamı yaratmaktır. İşte bu yolla artık arzu kavramı bir duruma karşılık gelen basit bir sözcük olarak tek boyutlu olmaktan kurtulacak, bir eylem ve etkinlik olarak kendi anlamını edimsel varlıkların ve tekilliklerin yaşayan dünyasında çoğaltacaktır. 
Bilgisayarının başında bunları yazmakta olan bu metnin yazarı bir dil-oyunu oynamaktadır. Bir dil-oyunu belki de kandırmaktan çok inandırmaktır. İnatçı okur bunu fark ettiğinde bu metinle bir dil-oyunu oynamaya davet edilmiş olacaktır. Ama yine de bu sözcükler bir uyarı olmanın ötesine geçemez. Uyarıyorum! sözcüğüyle oynanan bir dil oyunu mu yoksa?

\section{Karşılık ve Kullanım}

Felsefi Soruşturmalar, Augustinus'un İtiraflar'ından bir alıntıyla başlar. Bu alıntıda çocuk Augustinus, büyükleri bir nesneye yöneldiğinde, nesnenin ona ilişkin çıkardıkları seslerle imlendiğini, işittiği sözcüklerin hangi nesnelere işaret ettiğini de cümle içerisindeki tekrarlarla kavradığını söyler (Stroll, 2000, 132). Wittgenstein'a göre Augustinus bize burada bir dil resmi çizmektedir:

"Dilin bu resminde şu fikrin köklerini buluruz: Her sözcüğün bir karşıllğ̆ vardır. Bu karşılık sözcü̈ge eşlenmiştir; sözcüğün yerini tuttuğu nesnedir" (Wittgenstein, 2007, 23).

Her sözcüğün bir karşıllğı olduğunu ve sözcüklerin sadece nesnelerin adları olduğunu söylediğimizde, sözcük türleri arasında bir fark gözetme imkanını ortadan kaldırırız. Artık' masa' gibi bir sözcükle bir sayma sayısı örneğin 'beş' ya da etik ve estetik bir kavram olarak 'değer' aynı türden sözcükler olarak kurulur. Ben birine masa dediğimde o çevresindeki bir masayı işaret ettiğimi düşünür ve bakışını masaya çevirir, peki ya beş dediğimde beşi nasıl gösterecektir ya da değer dediğimde? Karşlık kuramı bize dilin ilkel bir resmini sunar Wittgenstein'a göre. Burada hemen şu soru sorulabilir: Sadece taşların adlarını bilmem satranç oyunu oynamam için yeterli midir? Örneğin tahtanın en solunda arkada duran taşın adını öğreniyorum birisi bana 'o taşın adı kaledir' diyor, ama bu bilgi bana o taşı nasıl kullanacağımı öğretmiyor ya da şöyle soralım: Karşılık modeli içerisinde kalarak bir oyun kurmak bir oyun oynamak mümkün müdür? Wittgenstein Felsefi Soruşturmalar'ın daha başlarında sözcüklerin nesnelerin adlarına karşıllı geldiği bir dil anlayışının ötesine geçecektir.

"Peki beş sözcü̈günün karşıllı̆ı nedir?- Burada söz konusu olan hiç de böyle bir şey değil, 'beş' sözcü̈̆̈̈nün nasıl kullanıldı̆̆ıydı yalnızca" (Wittgenstein, 2007, 24).

Wittgenstein'ın Felsefi Soruşturmalar'da karş11ık kuramının ötesinde sözcüklerin kullanımları temelinde bir dil anlayışına yönelmesi oyun kavramının kuruluşu bakımından nasıl yorumlanmalıdır? Bence, Wittgenstein'ın bu radikal hareketi, karşılık kuramı içerisinde oyunların ortaya çıkmasına imkan vermeyen bir dizi süreçten kopuş olarak yorumlanabilir. Wittgenstein, Augustinus'un dil anlayışı içerisinde sözcük türleri arasında bir ayrımın olmadığını, temelde 'masa', 'iskemle' gibi nesne adlarının referans olarak alındığını ve bir takım eylemlerin, etkinliklerin adlarınınsa ikinci sırada yer bulduğunu gösterir (Wittgenstein 2007, 23-4). Bu, tam da oyunlar hakkında konuşurken vurguladığı çeşitliliğe olanak vermeyen bir çerçevedir. Örneğin oyun oynamayı 'birtakım nesnelerin belli kurallar uyarınca bir düzlem üzerinde hareket ettirilmesi' olarak tarif etsek bu, Wittgenstein için sadece oyun tahtası üzerinde oynanan oyunları, satranç, dama etc. gibi oyunları içine alan bir tarif olur; oyunların tümünü içermez. Karşılık kuramı içerisinde kalarak betimlediğimiz dil, yalnızca bir anlaşma sistemi olarak dil kavramına götürür bizi. Peki dil yalnızca bir anlaşma sistemi olarak ele alındığında dışarıda kalan şey nedir?

"Wittgenstein bize diyordu ki dilin daima tek bir tarzda ve daima aynı amaca yönelik işlediği -düşünceleri tercüme etmek-düşüncesinden kopmak gerekir" (Hadot, 2009, 95). 
Dilin işleyişi dediğinde Wittgenstein, sözcüklerin kullanımları içerisinde oynanan oyunları, anlam ve kuralların dağılımını, dil oyunları arasındaki akrabalıkları devreye sokacaktır. Tractatus, anlamın da olgular tarafından dile getirilebileceği bir anlam kuramı geliştirmişti, Felsefi Soruşturmalar ise bize anlamın kullanımlar içerisindeki resmini çizer.

Felsefi Soruşturmalar'da dile ilişkin iki analojiyle karşıllaşırız: oyun ve labirent.

\section{Oyun-Labirent}

Felsefi Soruşturmalar'ın 18. fragmanında Wittgenstein dili eski bir şehir olarak görebileceğimizden söz eder. Bu şehir, geçitlerden, alanlardan, eski ve yeni evlerden, caddelerden, banliyölerden oluşmuş bir labirenttir aslında (Wittgenstein, 2007, 29). Labirent analojisi oyun analojisinin terk edilişi anlamına gelmez burada, tersine onunla bütünleşir. Labirentin içinde kimyanın sembolizmi ve sonsuz matematiğin notasyonu dilimizin kıyılarını oluşturur. Labirent, çıkmaz sokakları ve birbirine benzeyen duvarlarıyla yollarını içinde yürürken keşfettiğimiz bir tür oyundur. Bir labirent haritası onun dışından çizilebilir mi hiç? Labirent, sözcüklerin ve onlarla oynanan oyunların çeşitliliğine benzer bir şekilde görünüşteki birörnekliğinin ötesinde içinde yolların, çıkmazların, kayboluşların olduğu bir bilmece gibidir. Belki de dil oyunlarını, kesin bir tanım vermeksizin, bir çeşitlilik içinde, bir etkinlik, bir yaşama biçiminin parçası olarak görme girişimiyle labirent imgesi arasında derin ve organik bir ilişki vardır.

65. fragmanda Wittgenstein, dil dediğimizde tüm diller için ortak bir şey varsaymadığımızı tersine dillerin birçok yönden akrabalıklar taşıdığını söyler ve hemen sonra akrabalıklar kuramını oyunlar üzerinden tartışmaya başlar (Wittgenstein, 2007, 51). Peki, kesin bir oyun tanımı yapmak mümkün müdür? Wittgenstein için oyunlar, içlerinde bir dizi kurallar taşıyan süreçlerdir ama tüm oyunların kazanma amacı güttüğünü söyleyemeyiz. Örnek olarak bir çocuğun kendi başına legolarla birtakım şekiller yapması da bir tür oyundur ama kazanma amacı gütmez. Ya da tüm oyunların eğlendirici olduğunu söyleyebilir miyiz? Birçok oyun örneği verilebilir ve birisinde belirgin olan bir özellik diğerinde yitmiştir. Damayla sessiz sinema oyununu karşılaştırabiliriz. Dama, bir tahta üzerindeki taşların hareket ettirilmesiyle oynanan, kurallara karşı oyuncuların stratejiler geliştirdiği, rakibin taşlarını tüketmek üzerine kurulu bir oyundur, kazanma amaçlı bir oyun olarak çıkar karşımıza. Ama bir sessiz sinema oyununda amaçlanan jest ve mimiklerle birinin konuşmadan anlattığı bir filmin adını bulmaya çalışmaktır. Burada bir kazanma stratejisi değil bir bilmece anlatabilme ve okuyabilme yetisi öne çıkar. Bununla birlikte, oyun dediğimiz tüm bu süreçlerin birbiriyle birtakım benzerlikler taşıdığını söyleyebiliriz; benzer olan her şeyin daha baştan farklı olduğunu akılda tutarak. Oyun, çokluktur.

Oyun kavramı ailevi benzerlikler kuramının gelişiminde kilit bir yerdedir Wittgenstein için. Aile içerisinde nasıl ki fiziki benzerlikler ve mizaçlar bakımından benzerlikler ve farklılıklar mevcutsa oyunlar için de bu geçerlidir ve bize "oyunlar bir aile oluşturur" diyecektir Felsefi Soruşturmaların 67. fragmanında (Wittgenstein, 2007, 52).

Oyun kavramına bir sınır çekebilir miyiz ve sınır çekmeden onunla ne kastettiğimizi bilebilir miyiz? Sınırları çekilmeyen bir kavram nasıl bir kavramdır ve gerçekten de bize bir şey söyler mi? 71. fragmanında şöyle sorar Wittgenstein:

"Oyun kavramının kenarları bulanık bir kavram olduğu söylenebilirAma bulanık bir kavram aslında bir kavram mıdır ki?- Netliği bozuk bir fotoğraf insan resmi midir ki? Net olmayan bir fotoğrafin yerine net olanı koymak her zaman daha mi iyidir? Net olmayan çoğu kez aslında tam da ihtiyaç duyduğumuz şey değil midir?" (Wittgenstein, 2007, 53).

Birine bir oyun tanımı veremeyiz, oyunlarla ilgili birtakım örnekler verebilir ve bunları oyunlara örnek süreçler olarak anlamasını isteriz. Ancak onun bu örnekleri anlaması için bunları 
kullanması gerekecektir, çünkü anlam kullanım süreçlerinde açığa çıkan bir şeydir. Böylelikle bir dil-oyunu içerisinde oyun sözcüğüyle bir oyuna başlarız; sınırları belli bir tanım yerine diloyunlarının çeşitliliğinde bir anlam sürecine dahil oluruz. Dil, gerçekten de basit bir şekilde bir nesne olarak ele alınıp, sınırları çizilebilecek bir olgu değildir (Wittgenstein, 2007, 52). Oyunun bir tür dil-oyununa dönüşerek, bir benzerlik ağı içerisinde oluşturduğu benzerlik ilişkileriyle kavranması gibi dil de artık "tümce", "sözcük" gibi sözcüklerden oluşan bir benzerlik ağı içerisinde kavranmalıdır, dilsel etkinlikler süreci olarak düşünülmelidir.

Felsefi Soruşturmalar'in 83. fragmanında oyun, dil ve kural arasındaki ilişkiler betimlenir. Betimlenir diyorum, çünkü 109. fragmanda inceleme içerisinde varsayımsal olan hiçbir şeyin kalmaması gerektiği ve bir kurama dönüştüren açıklayıcı bir bakış yerine betimleme etkinliğinin geçmesi gerektiğini söyler Wittgenstein (Wittgenstein, 2007, 67). 83. fragmanda, kırda bir grup insanın topla oynadığı çeşitli oyunlardan bahseder, oyunu yarıda kesip şakayla birbirlerini kovaladıklarını anlatır (Wittgenstein, 2007, 59). Şimdi, dışarıdan bakan biri olarak topun her havaya atılışında ve topun her el değiştirişinde bir takım kurallar saptasak bu ne anlama gelir? Tersine onlar da şöyle söyleseler: kuralları süreç içinde koyuyoruz ya da bu kuralları süreç içinde değiştirme durumumuz söz konusu. Wittgenstein'ın oyunları oluş süreçleri olarak ele aldığını görüyoruz. Yani, oyuna girmeden önce oyunu belirleyen sabit kurallar yoktur; benzer bir şekilde bir sözcüğün dil-oyununa girmeden önce, belli bir kullanımından önce de ona bir takım kuralları referans alarak bir anlam veremememiz gibi. Oyun, kendisine özdeş bir kurallar bütünü değil, süreç ve etkinliktir; henüz kurallar ortada yokken oyun süreçleri gerçekleşir: oyun-oluş.

Böylelikle Felsefi Soruşturmalar'da oyun kavramının kuruluşunda sınır ve kural sözcüklerinin değişmez bir zeminden kullanımların ve dil-oyunlarının çokluğuna doğru kaydırıldığı bir oyunla karşılaşırız.

Wittgenstein dil-oyunlarına örnek olarak şunları verir:

"Emretmek ve emir uyarınca eylemde bulunmak, bir nesnenin görünüşünü ya da boyutlarını betimlemek, betime dayanarak bir nesne üretmek, bir olayı bildirmek, bir olay hakkında tahminler yürütmek, bir hipotez ortaya atmak ve bunu sinamak, bir deneyin sonuçlarını tablo ve çizelgelerle sergilemek, bir öykü uydurmak; bunu okumak, tiyatro oyunu oynamak, tekerleme söylemek, bilmece yanıtlamak, şaka yapmak; fikra anlatmak, uygulamal aritmetik problemi çözmek, bir dilden diğerine çeviri yapmak, rica etmek, teşekkür etmek, sövmek, selamlamak, dua etmek" (Wittgenstein, 2007, 32).

Dil-oyunlarının eskiyen, değişen birtakım süreçler olduğunu göstermişti Wittgenstein. Bu durumun Wittgenstein'ın Felsefi Soruşturmalar'da dili gündelik dil üzerinden düşünmesiyle ilişkili olduğu görülüyor. Hatta Soruşturmaların bir yerinde 'yeni olan, her zaman için bir dil oyunudur' diyecektir bize (Wittgenstein, 2007, 34). Dil-oyunları değiştikçe kavramlar, sözcükler ve anlamlar da onlarla paralel bir değişim gösterecektir. Dil-oyunları, yaşama biçimlerimize içkindir.

\section{Usta ve Kalfa}

Daha 2. fragmanda Wittgenstein sonra yeniden döneceği ünlü bir örnek verir. Bir yapı ustası olan A ile kalfası B arasında bir dil düşünelim. Bu dilin onların anlaşmalarına yarayacak bir dil olduğunu varsayalım. A yapı taşları kullanarak bir bina yapmaktadır ve B de onun ihtiyaç duyduğu şeyleri ona getirmektedir. Bunun için A 'sütun', 'kiriş' gibi sözcükler kullanır ve B de bunları ona getirir. Burada A sütun dediğinde aslında bir nesnenin adını söylemektedir, oysa B 
adını duyduğu nesneyi getirerek bir eylem gerçekleștirmektedir (Wittgenstein, 2007, 24). Karşılık kuramı içerisinde kalınarak bu eylem açıklanamaz, çünkü eğer sözcük sadece nesnelerin adıysa burada sadece bir işaret edimi gerçekleşebilir. Oysa B sanki ustası ona 'sütunu getir' demiş gibi davranır. 7. fragmanda Wittgenstein örneğine yeniden döner, dil oyunlarına ve öğrenme süreçlerine ilişkin önemli betimlemeler yapar. A ile B arasındaki gibi bir dil onun için ilkel bir dil olarak görülebilir ve sözcüklerin kullanım süreçlerinin bütününe dil-oyunları der. Bu oyunlar, çocukların bir dili öğrenme süreçleriyle iç içe olan bir oyun olarak görülür. 8. fragmanda bu örneğin daha da geliştirildiğini görürüz ve artık A, B'ye sadece 'sütun' demez, onun yerine örneğin 'üç plaka şuraya' der ve B üç adet plakayı A'nın göstermiş olduğu noktaya götürür (Wittgenstein, 2007, 26). Plaka sözcüğünün işaret yoluyla bir öğrenme sonucu ortaya çıktığını söyleyebiliriz, ama tam burada Wittgenstein bize şunu sorar 'şuraya ve bu' da işaret edilerek mi öğretilir?'

Wittgenstein ileride bir sözcüğün karşıllı̆ı ile onun taşıyıcısı arasında çok önemli bir ayrım yapar ki bu ayrım karşılık kavramını da artık nesne ve ad ilişkisinin ötesine taşır. Eğer karşılık dediğimiz şey sözcükleri nesnelerin adları olarak kuruyorsa, nesne ortadan kalktığında sözcüğün ve anlamın da yok olması gerekirdi. Örneğin ben, Platon dediğimde artık hayatta olmayan birine işaret ederim ama onun hakkında bir cümle kuruyor ve bunu kullanarak bir anlamdan söz edebiliyorum. İşte tam burada Wittgenstein Platon sözcüğünün karşılığının artık hayatta olmayan Platon olmadığını söyler bize. Hayatta olmayan Platon 'Platon' sözcüğünün taşıyıcısıdır. Sözcüğün taşıyıcısı artık yoktur ama sözcük bir anlama sahiptir. Karşılık, artık bir kullanım süreci içerisinde anlamını bulur ve anlam bir sözcüğün kullanımıyla açığa çıkar.

\section{Başkasının Ağrısı}

Oyun başkalarının nasıl oyun oynadığı seyredilerek öğrenilebilir mi? $\mathrm{Bu}$ yolla nelerin kural olduğu nelerin kural ihlalleri olduğunu nasıl ayırırız? Peki ya bu başkası tam da 'ağrı' sözcügüyle bir oyunun içindeyse? Örneğin başımızda çok şiddetli bir ağrı hissettiğimizi söylediğimiz bir arkadaşımız kendisinin de aynı ağrıya sahip olduğunu söylüyor ya da doktorumuz sanki bu ağrıyı ona tümüyle betimlemişim gibi bana ve arkadaşıma aynı ilacı yazıyor. Buradaki temel sorun bir iç duyumun bir başkası tarafindan bilinip bilinemeyeceğidir ki bu sorun özel bir dilin mümkün olup olmadığına ilişkin bir başka önemli soruyu doğurur. Özel dilin mümkünlüğüne ilişkin soruşturma Tractatus' un meta-dil projesinden başka bir bağlama gönderme yapar. Metadil arayışı dünyanın anlamını kendi dışında başka bir tutarlılık düzleminde izlerken artık söz konusu olan anlam, dil-oyunlarına içkindir. Mümkün olan ve olmayan, mantığın ve aşkınlığın sınırlarından çözümlenemez; mümkün olan ve olmayan dil-oyunları bağlamında düşünülebilir. Tractatus projesi bu açıdan dilegetirilebilirin sınırlarını çizer ve çizdiği sınır üzerinden dünyaya bakar. Bir olgu durumu ile ona ilişkin herhangi bir değer tümcesi arasında bu anlamda mantıksal bir zorunluluk yoktur.

"Dünyanın anlamı, dışında yatsa gerek. Dünyanın içinde her şey nasılsa öyledir, her şey nasıl olup-bitiyorsa öyle olup biter; içinde hiçbir değer yoktur-olsaydı bile hiçbir değer taşımazdı" (Wittgenstein, 2005, 167).

Wittgenstein'ın Tractatus Logico-Philosophicus'ta sergilediği dünya tasarımı olgu bağlamları yoluyla ve mantıksal uzam içerisinde kalınarak ifade edilir (Wittgenstein, 2005, 15). Ancak, dünya şeylerin basit bir toplamından ibaret değildir. Söz konusu dünya tasarımı, birbirinden yalıtılmış şeylerden değil kendisi gibi olmakta olan olgu bağlamlarından oluşur. Dünya bir ilişkiselliktir bu anlamıyla ama mantıksal uzam içerisindeki olgular yoluyla kendi belirlenimini edinir. Wittgenstein'ın Tractatus projesiyle Felsefi Soruşturmalar metni arasında basitçe bir kopukluk ya da süreklilik varsaymak mümkün değildir bu yüzden. Projeleri, hedefleri ve araçları açısından epey farklılıklar taşıyan bu iki metin arasında ilişkisellik kavramı devreye 
sokularak bir takım bağlantılar bulgulanabilir. Elbette sorun birinin diğeri için bir temel olması ya da birinin diğerini takip etmesi ya da etmemesi değildir. Asıl mesele Tractatus'un gösterdiği mantıksal uzam içindeki dilegetirilebilir olanın sınırlarının dil-oyunları yoluyla nasıl aşındırıldığını araştırmak olabilir. Bu açıdan Tractatus'un sonunda karşımıza çıkan merdiven metaforu tersine okunmaya açıktır. Tractatus, üzerine tırmanılacak olan mantıksal tümcelerin merdivenini inşa eder ama dünyayı görmekle yetinmeyen Felsefi Soruşturmalar onu içkin bir alanda, diloyunlarının oluş sürecinde, deneyimlemeye çabalar ve merdiveni, yukarıya çıkan bir araç yerine yani bir yeri ya da şeyi aşmanın bir aracı olarak değil bir köprü olarak kullanır. Ağrı sözcüğüyle bir oyun oynamak demek, mantıksal uzamın üstüne tırmanmak değil, merdiveni yatay hale getirmek ve dünyayla başka bir bağlantı kurmak için köprüde bir adım atmak anlamına gelebilir.

Wittgenstein $(2007,119)$ ağrı sözcüğüyle ağrının dışavurumları arasında bir ayrım yapar (Wittgenstein, 2007, 119). Aslında gözlemlediğimiz şey, birinin ağrı duyduğuna ilişkin birtakım ifadelerdir ve bu ifadelere karşı geliştirmiş olduğum inanma, güven duyma ya da duymama gibi tutumlar bu ağrı dışavurumunun ardında bir ağrı durumu varsayımımı güçlendirir. 303. fragmanda Wittgenstein şöyle der:

\section{"Başka birinin ăgrısı olduğuna inanabilirim yalnızca, ama benim ă̆rım olduğunu bilirim- Evet 'ă̆rısı var' yerine 'ăgrısı olduğuna inanıyorum' demeye karar verilebilir" (Wittgenstein, 2007, 120).}

Biri hiç ağrı duymadığı halde bir ağrı davranışı sergileyebilir, bu biri ben olabilirim, yine de bu dışavurumun ardında bir ağrıdan bahsedebilir miyiz peki? Tam tersi bir durumu da varsayabiliriz, biri çok ağrı duymasına rağmen bunu dışa vurmamaktadır. Bu durumda onun ağrı duymadığını $\mathrm{m}$ söyleyeceğiz? Peki, biri kalkıpta bir duvarın ağrı duyduğunu iddia ederse cansız şeylerin ağrı duyamayacağını iddia edip çıkabilir miyiz bu sorunun içinden? Peki, 'ağrı' sözcüğüyle bir dil-oyunu nasıl oynanmaktadır? 293. fragmanda Wittgenstein çok önemli bir örnek verir. Bu örnekte varsayımsal olarak herkesin bir kutusu vardır ve kutunun içinde 'böcek' denen bir şey. Herkes yalnızca kendi ağrısını bildiği gibi yalnızca kendi kutusundaki böceği bilmekte ve kimse kimsenin böceğine bakmamaktadır (Wittgenstein, 2007, 118). Böcek denilen şeyi herkes kendi kutusundaki böcekten bilir tıpkı ağrı denen şeyi kendi ağrısından bilmesi gibi. Ama herkesin kutusundaki şey farklı bir şey olabilir:

"Kutunun içindeki şey dil-oyununa hiç mi hiç dahil değildir; bir 'bir şey' olarak bile: çünkü kutu boş bile olabilir" (Wittgenstein, 2007, 118).

Özel duyumların ifadelerinden oluşan bir dil yalnızca benim anladığım karmaşık seslerden örülü bir dildir. Bir dil-oyununun bir yaşama biçiminin parçası olduğunu söyler Wittgenstein, özel duyumlarla oynanan oyunlar da bunun dişında tutulamaz.

"Aclsını söylemek, bir dil oyunu oynamaktır; yani sempatiye, yardıma ya da anlaylşa hitap etmek için ancak toplum içinde bir anlama sahip olan bir tutum takınmaktır" (Hadot, 2009, 85).

\section{Emir ve Gramer}

Felsefi Soruşturmalar araştırmanın yönünü, gündelik dilin üzerindeki bir ideal dilden diloyunlarının çeşitliliğine, gündelik dildeki kullanımlara ve gramerin doğasına doğru çevirir. Gündelik dil, birörnekliğinin aksine derindeki kullanımların zenginliğiyle örülüdür. Örneğin emirlerin ve bu emirlerin yerine getirilmesinin gündelik dildeki kullanımları çeşitlilik taşır. Emrin kullanımı emir kipini aşar. 458. fragmanda Wittgenstein şöyle söyler:

"Emir, yerine getirilişini emreder. Yani emir, yerine getirilişinin ne olduğunu bu henüz ortada yokken bilir mi?" (Wittgenstein, 2007, 150). 
Gramer, bir tür temel olarak düşünülmüştür burada. Dilsel labirentin incelikli bir haritası olarak gramer, geçitleri, caddeleri ve çıkmazlarıyla bu eski şehrin içine çizilmiş bir haritadır. Özün gramerde dile getirildiğini söyleyecektir bize Wittgenstein. Peki, burada tözsel bir nitelik mi yükler gramere? Gramer, bu antik şehrin bir haritası olarak yorumlanmalıdır. Şehrin sokakları eskidikçe ve yerine yeni caddeler yapıldıkça, yeni yapılar meydana geldikçe bu harita da değișecektir ve gramerin değişmeyen bir yapı olmak anlamıla tözsel olarak yorumlanması mümkün görünmemektedir. Bir temel olması itibariyle gramer, labirente içkin bir haritadır ama tamamlanmamış, sınırları ve kuralları oyunlarla birlikte değişen bir harita.

431. fragman bize 'emir ile yerine getirilişi arasında bir uçurum vardır' der ve bu uçurumun anlamayla doldurulabileceğini söyler (Wittgenstein, 2007, 146). Diyelim ki ben bir emir veriyorum 'bu kitabı şuraya götür' gibi bir emir. Birinin kendine verdiği emirleri saymazsak bir emir hep bir başkasını varsayar. Bu başkası ne dediğimi anlamıyor ve emri yerine getiremiyor. Ama bu emrin ne anlama geldiğini anlayan bir başkası da emri bilinçli olarak yerine getirmiyor. Emir, kendisinin uygulanışından bağımsız olarak var olabilir gözükse de bir emrin yerine getirilişi emirden bağımsız olarak var olabilir mi? Verdiğim emri duymayan ama emrin uygulanışını gören biri, bunu (kitabın şuraya götürülüşü) bir emrin uygulanışı olarak mı görür? Ama emirlerle oynanan dil-oyunları da diğer oyunlar gibi bir yaşantıyla ve bir yaşama biçiminin parçası olarak gelirler. Okul, kışla, akıl hastanesi, cezaevi tüzükleri bir 'rehabilitasyon' ve 'topluma hazırlama' söylemiyle ifade edilirken, emrin içinde olduğu bir tür gramerle ilişki kurulmaksızın düşünülebilir mi artık? Belki de emirsiz bir yaşama tarzı için bir tür ipucu taşır dil-oyunları içlerinde. Emri kendisine karşı çevirecek bir stratejiye olanak tanırlar.

\section{Arzu ve Dil Oyunları}

Bir emir nasıl ki 'emrediyorum' gibi bir tümcenin sınırlarının dışında emir ve uygulanışı arasındaki uçurumda temellenen etkinliklerle dil-oyununa dahil olursa, arzu da 'istiyorum'un dışında, 'tatmin olmamışlığın' dışında üretici bir etkinlik olarak arzulama kavramıyla ifade edilebilir. 440. fragmanda Wittgenstein arzuyla tatmin edilmemişliği birbirinden ayırır.

“'canım elma çekiyor' demek şu demek değildir: elmanın, tatmin edilmemişlik hissimi gidereceğine inaniyorum. Bu tümce arzunun değil, tatmin edilmemişliğin dışavurumudur" (Wittgenstein, 2007, 147).

Wittgenstein 'emir, yerine getirilişini emreder' diyordu, belki de arzu kavramı için buradan hareketle şöyle söyleyebiliriz: arzu kendinin gerçekleşmesini arzular ya da arzu, kendi gerçekliğini üretir. Arzu ve onun gerçekleşmesi bir dil-oyunu içerisinde birbiriyle buluşur. Wittgenstein, arzu ve arzulanan şey arasındaki ilişkiden, beklenti ile gerçekleşmesinin diloyunlarındaki görünümlerine geçer ve birkaç örnek verir. Bunlardan birinde, birisinin nişan aldığını görür ve 'bir patlama bekliyorum' derim. Ardından atış yapılır (Wittgenstein, 2007, 147-8). Atışla birlikte bir gürültü de duyarım ve şu soruyu sorarım: bu gürültü de beklentim de içerilmiş miydi? Belki de gürültünün kendisidir beklentimi gerçekleştiren. Tam bu geçidin sonunda Wittgenstein çok zekice şunu sorar:

\section{"Patlama beklediğim kadar gürültülü değildi- beklentinde daha mı gürültülü patlamışt yani?" (Wittgenstein, 2007, 148) .}

Wittgenstein'ın arzuyu bir eksiklik olarak anlayan düşünce imgelerinden kopararak, arzuyu kendi gerçekleşmesiyle bağlantılı olarak, dilsel bir süreçte ifadesini bulan bir etkinlik olarak düşünmesi bence yeni bir arzu kavramının kapılarını aralar. Arzulamak dediğimizde artık nesnesinden yoksun bir öznenin yönelimini anlamayız bu düşünce içinde. Arzu da bir dizi kullanım içinde yeni anlamlar kazanır. Arzulamanın 'tatmin edilmemişlik' olarak düşünüldügü 
bir dil-oyunu artık yerini, arzunun olumlu anlamlarını öne çıkaracak bir şekilde bir 'süreç', 'oluş', 'etkinlik' olarak anlam kazandığ 1 bir oyuna bırakır. Bu da arzuya ilişkin yeni bir diloyunu yani yeni bir yaşantı, yaşama tarzı demektir.

\section{Sonuç Yerine}

\section{Forte}

Wittgenstein'ın Felsefi Soruşturmalarını okurken, metnin bir labirent-oyun olarak örüldüğünü düşündüm. Wittgenstein bu metinde oyun etkinliğini, kurucu bir kavram olarak işletmiş görünüyor; ama bu, sistematize edilebilir türden bir kuruluş gibi görünmüyor. Kendisinin de söylemiş olduğu gibi açıklamalardan betimlemelere doğru bir geçiş var bu metnin örgüsünde. Bu yüzden bir oyun tanımıyla başlamak yerine onları örnekler içinde, gündelik dil içinde betimliyor.

Kullanım etkinliği burada en göze çarpan betimlemelerden biri. Burada dilsel olaylara ilişkin bakış açılarında büyük bir kırılma karşısındayız. Kullanım teriminin gelişimiyle, karşılık kavramı nesne-ad ilişkisinden bir adın taşıyıcısıyla ilişkisine doğru kaydırılıyor. Bu da dil oyunlarının çeşitliliği içerisinde oyun oynamayla dil arasındaki bir dizi benzerliğin üretilmesiyle ilerleyen bir sürece dönüşüyor.

Bir oyun tanımı yerine Wittgenstein, oyunlar arasındaki benzerlik ağı olarak aile benzerlikleri kavramını üretir. $\mathrm{Bu}$, oyunların bir aile oluşturma süreçlerine ilişkin bir kavramdır. Benzer bir şekilde dil dediğimiz şey de benzerlik ağları yoluyla bir tarif edinir, herhangi bir nesnenin tanımlanma biçimlerinin ötesinde.

Wittgenstein'ın metninde çarpıcı olan bir betimleme de onun 'arzulamak' üzerine söyledikleridir. Arzu kavramı, artık bir eksiklik, hiçlik imgesinden koparılır; bir etkinlik ya da süreç olarak dil-oyunları içinde üretici bir karakter edinmektedir. Arzu, kendi gerçekleşmesini arzular.

\section{KAYNAKÇA}

Altınörs, A. (2002). Dil Felsefesi Sözlüğ̈̈. İstanbul: Paradigma Yayınları.

Borges, J. L. (2007). Ficciones. Çev. Tomris Uyar, \& Fatih Özgüven. İstanbul: İletişim Yayınları.

Deleuze, G. (1990). The Logic of Sense. Trans. by Mark Lester, \& Charles Stivale. New York: Columbia University Press.

Deleuze, G., \& Guattari, F. (1994). Anti-Oedipus. Trans. by Robert Hurley, Mark Seem, Helene R.

Lane, The Athlone Press, London.

Glock, H. J. (2008). What is Analytic Philosophy. New York: Cambridge University Press.

Hadot, P. (2009). Wittgenstein ve Dilin Sinırları. Çev. Murat Erşen. İstanbul: Doğu Batı Yayınları.

Saussure, F. (1998). Genel Dilbilim Dersleri. Çev. Berke Vardar. İstanbul: Multilingual.

Soykan, Ö. N. (2006). Felsefe ve Dil. İstanbul: Mtv Yayınları.

Stroll, A. (2000). Twentieth-Century Analytic Philosophy. New York: Columbia University Press.

Wittgenstein, L. (2005). Tractatus Logico-Philosophicus. Çev. Oruç Aruoba. İstanbul: Metis Yayınları.

Wittgenstein, L. (2007). Felsefi Soruşturmalar. Çev. Haluk Barışcan. İstanbul: Metis Yayınları. 
